\title{
Heat transfer of brake pad used in the autos after friction and examination of thermal tension analysis
}

\author{
M. Timur*, H. Kuşçu** \\ *Kırklareli University,Voc. Sch. of Tech. Sciences, 39100 Kirklareli, Turkey,E-mail: mustafatimur@kirklareli.edu.tr \\ **Trakya University, Faculty of Engineering and Architecture, 22000 Edirne, Turkey, E-mail: hilmi@trakya.edu.tr \\ cross ${ }^{\text {ref }} \mathrm{http} / / / \mathrm{dx}$. doi.org/10.5755/j01.mech.20.1.6595
}

\section{Introduction}

The brakes used in the autos are energy changing tools. They convert the mechanic energy of car into heat energy through friction. The car on the move has kinetic energy. In the braking systems, the kinetic energy of the car is converted into heat energy via the friction of the pads onto disc and this heat emits the atmosphere. If the brakes are given heat more than they can emit to environment, the friction parameter in brake pads declines and the stopping capability of the brakes decreases. After this point, wear is accelerated. The continuous exposure of the brake pads to over temperature leads to the exhaustion of the braking performance of pads. This situation shows itself as decrease, malfunction, fast pad wear and sound in the performance of brakes [1, 2]. Hohmann et al. [3] determined high pressure in the outer radius of pad and pad supporting plate as a result of the analysis they carried out at the end of braking. In their study, Tamari et al. [4] made about the prediction of contact pressure in disk brake pads stated that the contact pressure must be proper in disk brakes so that wear can be proper. Abu Bakar et al. [5], tried to model the pressure distribution between pad and disk in computer environment using different design, dimension and material. They found out that the asymmetric and improper pressure distribution cause improper wear and shortening of pad life. They concluded that pad construction is influential on pressure distribution and wear. Abu Bakar et al. [6] made three dimensional analysis of contact pressure distribution over disc and pad surfaces using brake and finite element model. The conduction hardness of asymmetrical solid matrix, friction parameter in disk and pad interface constituted the core of the method. They researched model brake disks and contact pressure distribution at different levels. Using a proper model, it was provided to make the predictions of pressure distributions in the interfaces in brake disks. Abu Bakar et al. [7], experimentally found the noise and sound vibration which stem from dynamic ambiguity because of friction during braking and examined the data using Abaqus packet program. In their study, Valvano and Lee [8] examined thermal attitude under short term and stable state. The maximum temperature of the disk is found in the place where a contact is made with pad and they found that the temperature rose at the time of repeating braking. In his study, Arpat, [9] examined the amount of wear of the pads in drum or disk brake systems occurring because of the increase of heat on the surface of friction as a result of frequent braking of light and heavy commercial vehicles. He found out that with the decrease of temperature at the moment of braking, wear in the pad declined. Jacobsson [10], made a conven- tional disk brake analysis. He reached the conclusion that thermal degradation occurred because of friction depending on the time, and mechanic degradations because of operating forces applied. As a result of the experimental study, it was found that wear appeared in the friction material couple and there was a decrease in the thickness of the disk. Mosleh et al. [11] made analyses about the wear and friction behaviours in the pads which were exposed to braking at different speeds and the tribological characteristics of erosive materials. In the tests experimentally achieved, the characteristics of brake material were determined. Depending on the differentiality of the brake material, they determined that the change in the wear rate was dependent on the low and high sliding speeds. Hwang et al. [12] defined the thermo elastic irregularity resulting from the heat which occurred because of friction at the time of braking. They tried to solve the heat and thermal deformation change under a single proper braking and repeating braking through the method of finite elements. They found that the maximum temperature of the disk is found in the place where a connection is made with the pad and occurs during repeating braking. Li et al. [13] argued that the occurrence of vibration and noise at the time of braking in the disk brakes result from pressure and heat distribution on the surface of pad. As a consequence of the experimental studies and numerical analyses, it was seen that the temperature distribution was not appropriate and there was high pressure in the locations where temperature value was high. They ascertained that temperature was effective in noise and vibration occurring on the surface of pad.

In this study, the temperature-stress distribution and change occurring during braking of brake pad material was examined. The thermal and mechanic features of four different pad materials which were mentioned earlier as pad material in literature, the thermal and mechanic behaviour of the pads were tried to be determined using SolidWorks Simulation Solutions program. In addition, in the study, the impact of wear rate of pad was aimed to be revealed. The thermal power forming through the conversion of motional energy into thermal energy during braking was mathematically calculated. Using SolidWorks software program, the pad in the brake system was modelled, and the calculated thermal power was entered in the program and analysis results were obtained [14].

\section{Material and method}

\subsection{Material}

In this study it is aimed to determine the effects of thermal and mechanic characteristics of various materials developed as pad material on pad. As a result of literary 
survey made for this purpose, the characteristics of material developed by different researchers were taken into consideration. The characteristics belonging to the materials were given in Table [1].

In the Table of material Nol was made of carbon-carbon combined composite material. As seen in the Table, it is the material that has the highest specific heat. Its density and heat conductivity parameter is also high. It is the material whose Poisson ratio is the highest.

Material No2 was made of carbon-carbon com- bined composite material. It is the second highest material in terms of thermal expansion parameter. Comparing with material No1, its thermal conductivity parameter is ten times and its elasticity module is fifty times smaller.

Material No3 is the material that has the smallest elasticity module and thermal conductivity parameter. In terms of density value, it is the second highest material.

Material No4 is the material that has the highest density value, the lowest thermal expansion parameter and specific heat value.

Properties of pad materials

Table

\begin{tabular}{|c|c|c|c|c|c|c|c|}
\hline $\begin{array}{c}\text { Material } \\
\text { No }\end{array}$ & $\begin{array}{c}\text { Thermal conductivity } \\
\text { coefficient, } \\
k, \mathrm{~W} / \mathrm{mK}\end{array}$ & $\begin{array}{l}\text { Specific } \\
\text { heat, } c \text {, } \\
\mathrm{j} / \mathrm{kg} \mathrm{K}\end{array}$ & $\begin{array}{l}\text { Density, } \\
\rho, \mathrm{kg} / \mathrm{m}^{3}\end{array}$ & $\begin{array}{c}\text { Thermal expan- } \\
\text { sion coefficient, } \\
\qquad \alpha, 10^{-6} / \mathrm{K}\end{array}$ & $\begin{array}{l}\text { Young's } \\
\text { modulus, } \\
E, \text { GPa }\end{array}$ & $\begin{array}{c}\text { Poisson's } \\
\text { ratio } \\
v\end{array}$ & Reference \\
\hline 1 & 50 & 1880 & 1800 & 0.3 & 50.2 & 0.3 & Choi [15] \\
\hline 2 & 5 & 1000 & 1400 & 10 & 1 & 0.25 & Choi [15] \\
\hline 3 & 0.5 & 1034 & 3660 & 30 & 0.53 & 0.25 & Hwang [12] \\
\hline 4 & 5 & 350 & 4000 & 0.001 & 1 & 0.25 & Voldrich [16] \\
\hline
\end{tabular}

2.2. The geometry of the problem and limit conditions

The geometry of the examined pad was given in Fig. 1, a. This pad is situated on a $187 \mathrm{~mm}$ diameter disk as seen in Fig. 1, b. For the problem, in all of the materials as a common value $\mu=0.45$ was taken. In this case, depending on the distance of each nodal point of the object to the center, thermal power was calculated as

$$
\begin{aligned}
& \rho=\mu \times P \times A \times \omega \times R ; \\
& \rho=0.45 \times 1050000 \times 0.00305 \times 64.3 \times R ; \\
& \rho=92800 \times R .
\end{aligned}
$$

The brake pressure was $P=1050 \mathrm{kPa}$, rotation speed was $\omega=64.3 \times \frac{1}{S}$ and pad surface space was $A=0.00305 \mathrm{~mm}^{2} . R$ shows the distance of the examined point from the center of the pad.

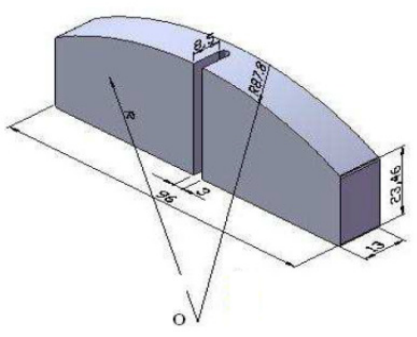

a

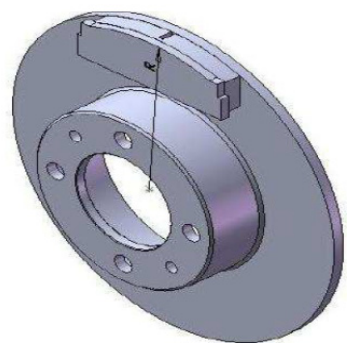

b
Fig. 1 The geometry measurement of pad (a) the brake disk-pad view (b)

Pad was accepted under room temperature in the beginning. The thermal heat condition applied for the pad under these conditions was given in Fig. 2, a. It is seen that $10 \%$ of heat input $q_{i}$ is emitted from the back surface of the pad. From other surfaces, however, there is heat transfer through convection. Here the convection coefficient was taken as:

$$
h=28\left(\frac{w}{m^{2} K}\right) .
$$

While taking these values, the formula of:

$$
h=10.45-V+10 \sqrt{V}
$$

Air speed $V$ was taken as the peripheral of the disk [17].
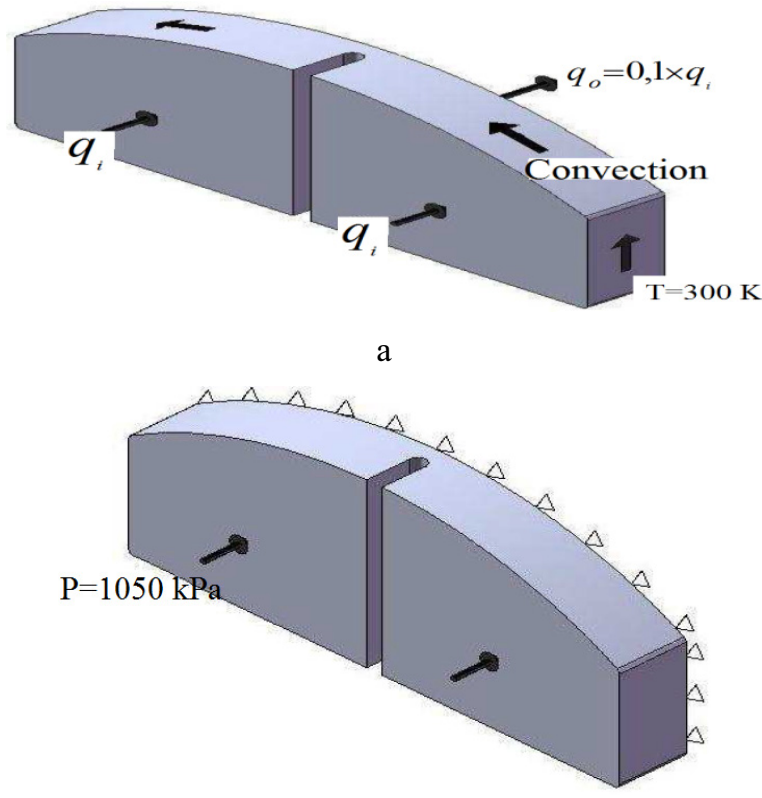

b

Fig. 2 The heat input $q_{i}$ - output $q_{0}$ limit conditions applied on the pad are thermal (a) and mechanical (b)

The mechanical limit conditions applied to the problem are shown in Fig. 2, b. Since pads were produced 
as stuck on a base, the bottom of was taken stable. A pressure of $1050 \mathrm{kPa}$ was applied on the surface between the pad and disk [14]. The problem was solved under these conditions considering different ways of wear (unweared, $6 \mathrm{~mm}$ weared) for the wear occurring at the end of $300 \mathrm{~s}$. While composing finite member net, triangular pyramid which is most suitable member type in the modelling of curved edges was chosen, it was provided to compose thinner member in the regions where temperature change is huge across the thickness. The net structured obtained were given in Fig. 3. According to the wear states of Material 1, there are 19806 nodal points for the unweared and 22783 for the weared respectively [14].

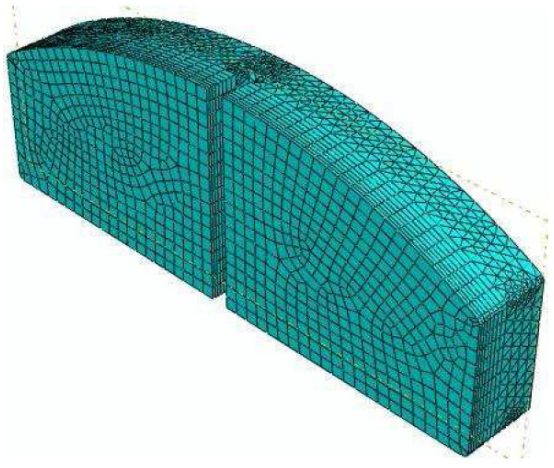

Fig. 3 Mesh view of brake pad

\section{Findings and discussion}

The findings of the analyses made in this part were given in two sections for the temperature analyses first and for the stress analyses then.

\subsection{Findings with temperature}

In the findings section about temperature, firstly, as a result of the solution made for $300 \mathrm{~s}$, figures belonging to the temperature distribution attained in the pad were given. Temperature distributions and deformation states after braking in the unweared (a) and $6 \mathrm{~mm}$ weared (b) pad at the end of $300 \mathrm{~s}$ were given in Fig. 4.

As seen, in all figures, depending upon the radius of the pad, the temperature emerging in the outer part is higher. Besides, it is seen that temperature is decreasing from the surface of pad touching disk towards outside. For pad, besides the surface temperature, the spread of heat in the pad is also important. For this reason, while making a comparison among the materials, it is necessary to be careful with both maximum and minimum values and the difference between them. The unweared pad material is at $\mathrm{No} 3$, the highest surface value is $206^{\circ} \mathrm{C}$ and the lowest surface temperature value is $203^{\circ} \mathrm{C}$, the difference of temperature is $3^{\circ} \mathrm{C}$. The reason for this is that the thermal conductivity parameter is low and specific heat value is not high. Taking the wearing rate into account, the surface temperature of the $6 \mathrm{~mm}$ weared pad material is $509^{\circ} \mathrm{C}$ at $\mathrm{No} 3$ and the lowest surface temperature value is $502^{\circ} \mathrm{C}$, the difference of temperature is $7^{\circ} \mathrm{C}$. Considering the wearing rate in Material No3, when the rate of wear rises, the temperature occurring on the surface and the temperature difference between two surfaces also rises. In other materials as well, with the increase of wear rate, the temperature value occurring on the pad surface and the temperature difference between two surfaces rises as well. In the unweared pad material series, the highest temperature occurring on the surface was at material No3. The highest temperature occurring on the surface of $6 \mathrm{~mm}$ weared pad series is seen to emerge in material No3. The specific heat, density and heat conductivity parameter multiplication of material No2 and No4 are equal and higher than material No3. As the heat conductivity parameter, specific heat and density values are high in material No1, the temperature value occurring on the surface of pad is lower comparing with other material series. The highest surface temperature existing in this material is $206^{\circ} \mathrm{C}$ for the unweared, $509^{\circ}$ for $6 \mathrm{~mm}$ weared, and the lowest surface temperature is $203^{\circ} \mathrm{C}$ for the unweared, $502^{\circ} \mathrm{C}$ for $6 \mathrm{~mm}$ weared and the temperature difference between two surfaces is $5^{\circ} \mathrm{C}$ on average.

If the thermal heat conductivity and density value of the material is high, the temperature difference on the surface is low. If the density and heat conductivity parameter of the material is low, the temperature value forming on the surface becomes high. If the temperature difference between the pad surfaces had been high, the temperature shapes on the surface would have taken quite a messy shape. Because the temperature difference between the pad surfaces in unweared and $6 \mathrm{~mm}$ weared pad materials surface, temperature shapes seem to exist in a place close to pad center and in round shape [14].

As seen in Fig. 4, generally in the rate of wear of pad materials, there is a lineer increase in the pad surface temperatures according to wear rates. The surface of pad material rubbing against disk often plays a determining role among temperatures. with the fact that wear rate is $6 \mathrm{~mm}$, there is seen a significant rise in pad temperatures in different materials in the same time period. The temperature difference occurring in material No3 whose thermal conductivity parameter is the lowest becomes the highest. However, in material No1 whose thermal conductivity parameter is the biggest, the pad temperature difference is very low. Since the thermal conductivity parameter of material No2 and No4 is equal, the shapes showing the temperature value on the surface that changes according to unweared and weared amounts are similar [14].

\subsection{Findings with stress}

In the chapter concerned with the results of strain, the shapes about the strain distribution obtained in the pad as a result of the solution made for $300 \mathrm{~s}$ were given. Stress distributions and deformation states after braking in the unweared (a) and $6 \mathrm{~mm}$ weared (b) pad at the end of $300 \mathrm{~s}$ were given in Fig. 5. The places where stresses emerged most are the corner parts where the surface of pad is held and the middle channels of pad. In terms of thermal stresses, the most important subjects are the thermal expansion parameter and module of elasticity. For this reason, while comparing the stresses, this characteristic of the material needs to be considered. On the other hand, the highest temperature and temperature differences occurring in the material are the factors which become influential in the formation of thermal stresses.

As the thermal expansion parameter of the unweared material No4 is the lowest, the stress distribution emerging on the surface contacting with the disk is proper. 


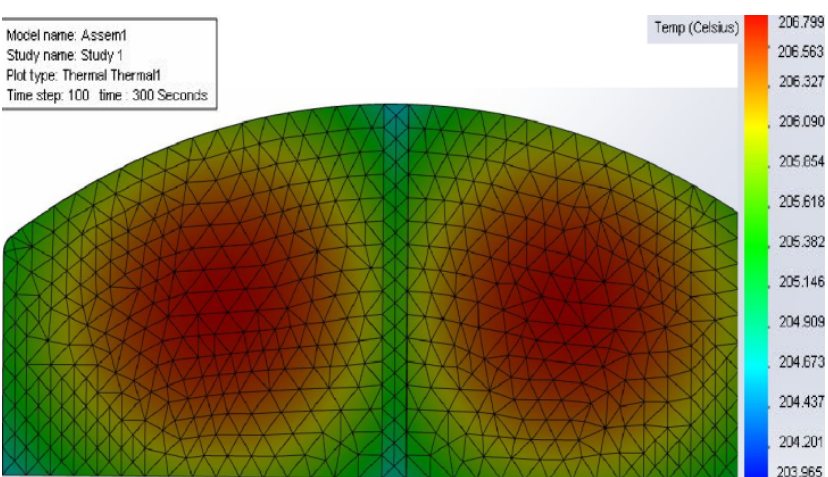

a

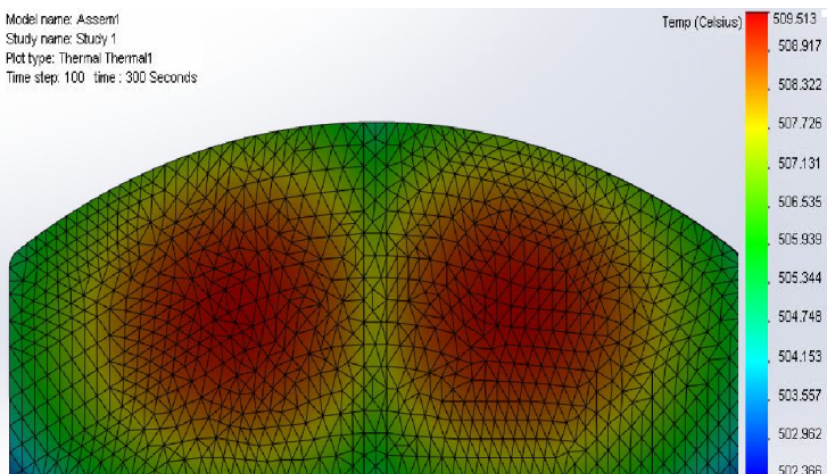

b

Material 1

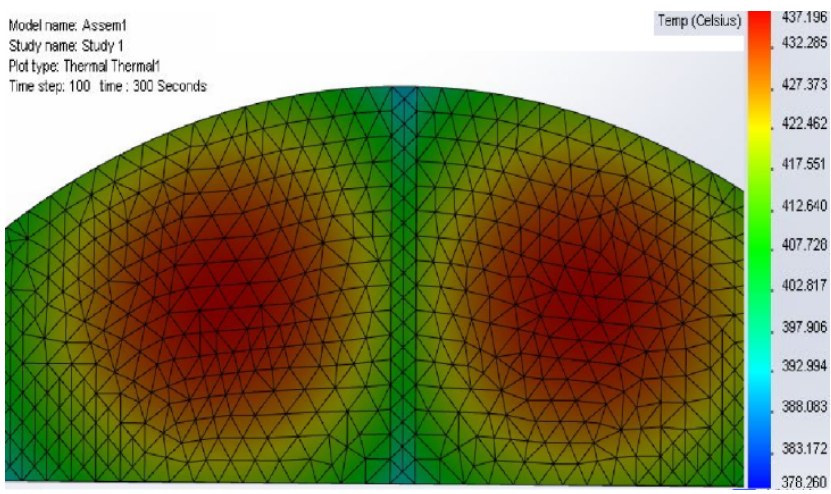

a

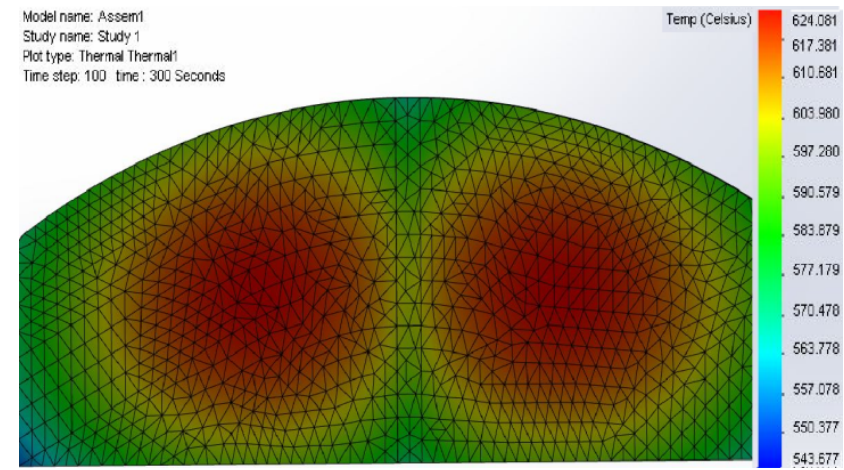

Material 2

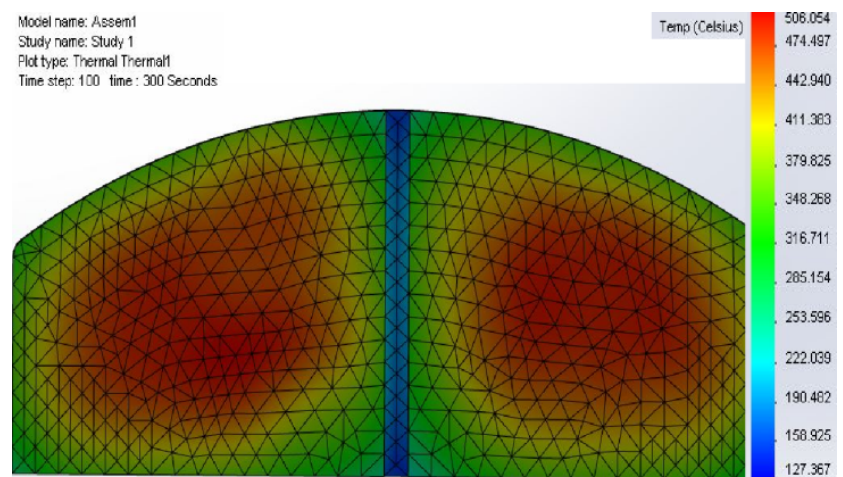

a

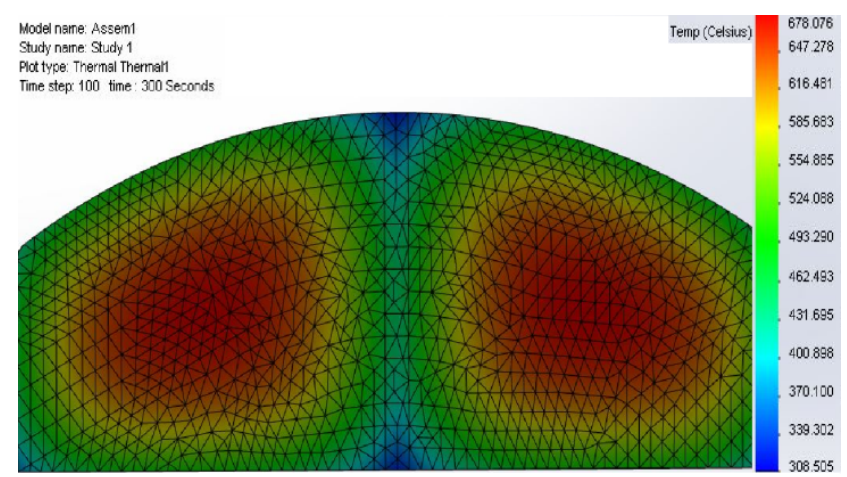

b

Material 3

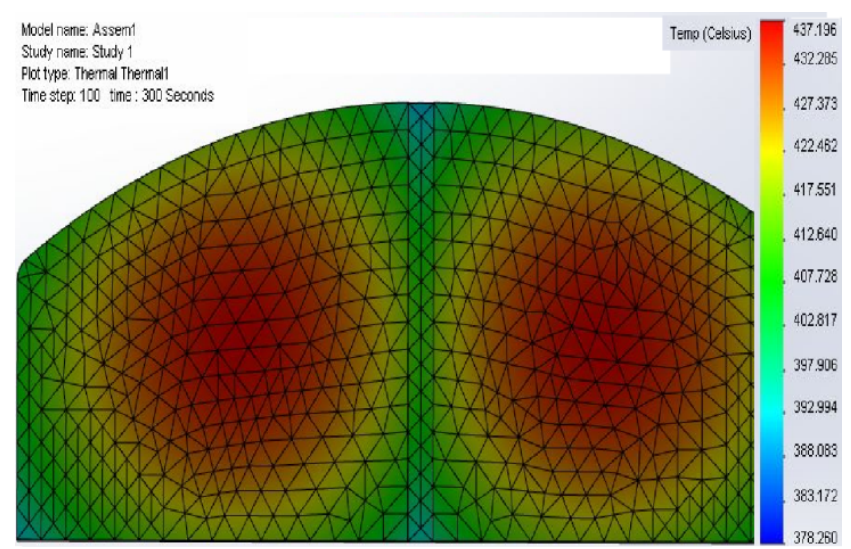

a

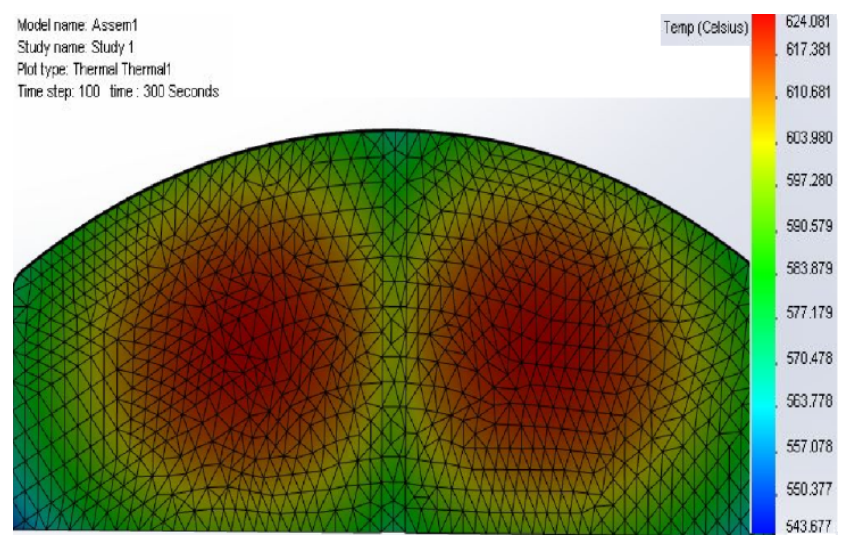

b

Material 4

Fig. 4 Temperature distributions and deformation states after braking in the unweared (a) and 6 mm weared (b) pad at the end of 300 seconds 


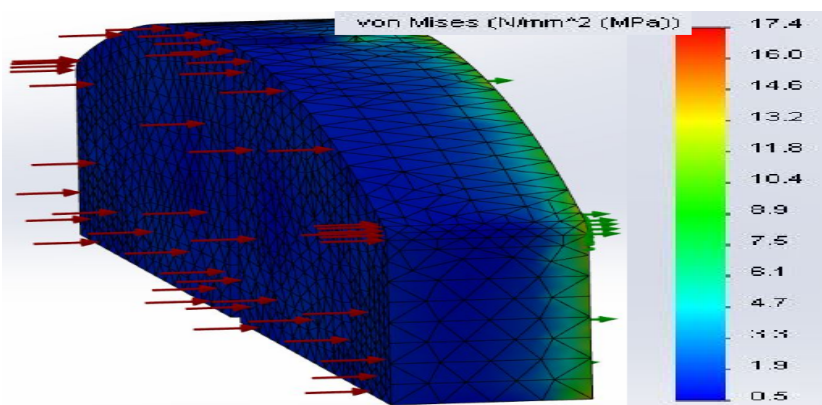

(a)

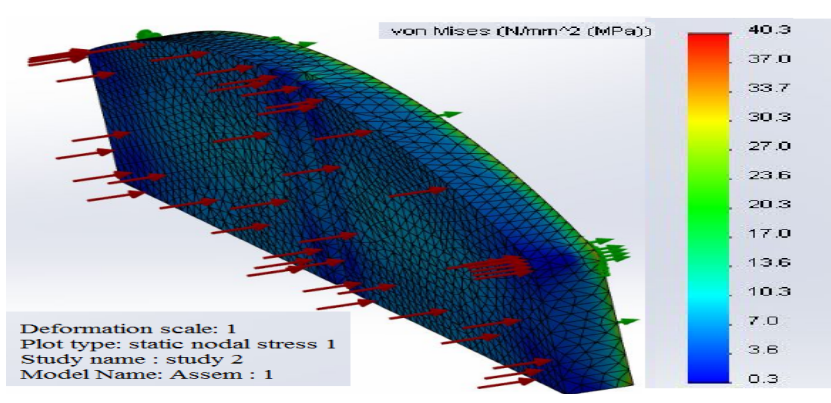

(b)

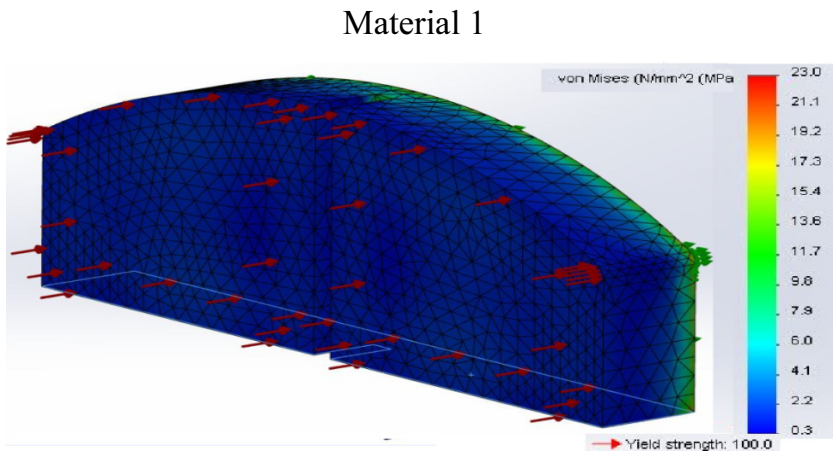

(a)

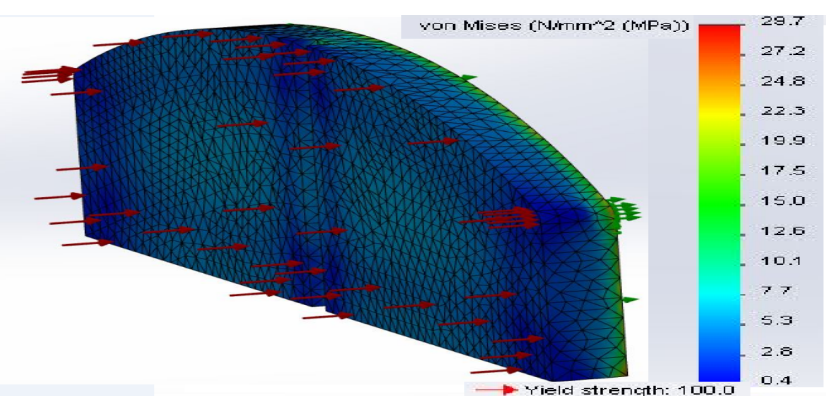

(b)

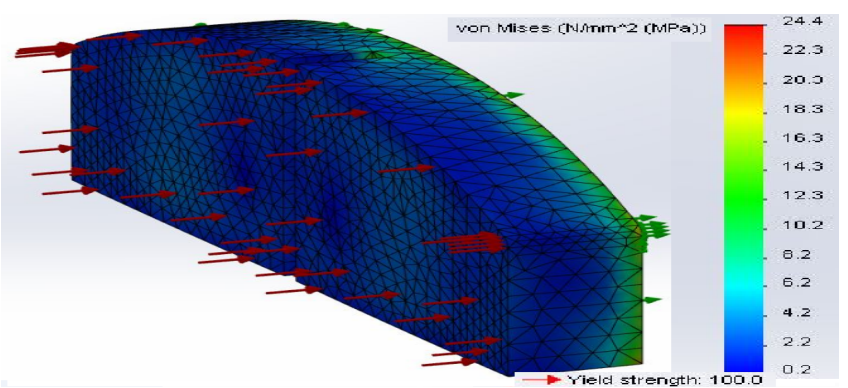

(a)

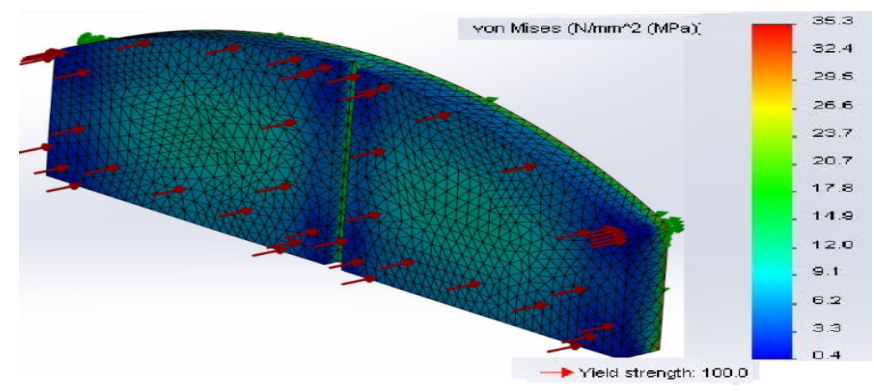

(b)

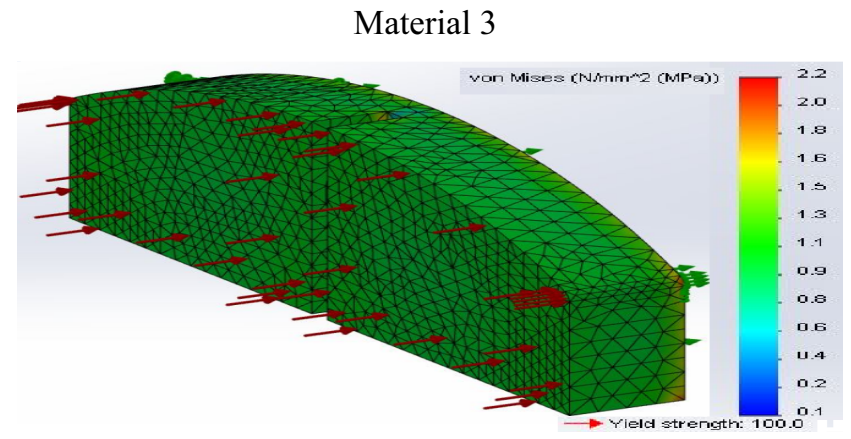

(a)

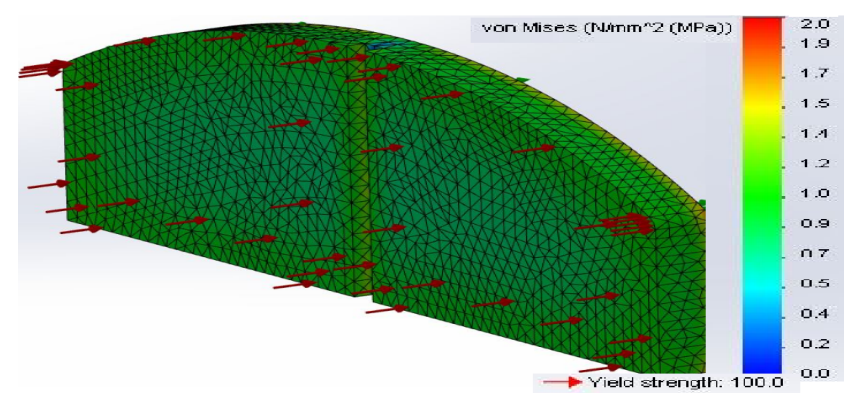

(b)

Material 4

Material 2

Fig. 5 Stress distributions and deformation states after braking in the unweared (a) and $6 \mathrm{~mm}$ weared (b) pad

On the contrary to this, the biggest strain value emerging in the pad is $2.2 \mathrm{MPa}$ which is the lowest value comparing with the other unweared materials. Comparing it with $6 \mathrm{~mm}$ weared materials in terms of the strain value occurring on its surface, it is seen that the lowest value is got. Although the material characteristics of stress values occurring in the unweared and $6 \mathrm{~mm}$ weared material No4 are the same, the fact that they happened to result differently is seen to stem from the biggest and lowest temperature value emerging on its surface and the difference between this temperature value. It is observed that the stain in unweared pad material emerges in the biggest value 24.4 $\mathrm{MPa}$ and material-3. In the $6 \mathrm{~mm}$ weared pad mate- rial, however, the biggest strain value is in the material No3 with $35.3 \mathrm{MPa}$. The multiplication of elasticity module and heat expansion parameter of this material is the highest. That the strain value forming through the materials whose multiplication of elasticity module and thermal expansion parameter are low is also low is seen in Fig. 5. The stress distribution occurring on the surface of the pad touching the disk shows a quite proper view except for the Material No1 and No3. However, these two materials display a higher distribution in the sides and lower in the inner parts. For these materials, the multiplication of elasticity module with thermal expansion parameter takes nearly the same value [14]. 
The change of the stresses talent from four material in time is shown in Fig. 5 The stress values obtained while composing these shapes were divided to $1050 \mathrm{kPa}$ strain value which was applied on the surface and they were made non-dimensional. Each shape shows different situations depending on the wear amount for a material. In all of the pads, there is an amount of wear at first, later stresses begin to increase. This decline period is short or long depending upon the thermal characteristics of the materials. For example, in the material No4 whose thermal capacity is the lowest, there hasn't been any rise during braking time. In other materials, however, there was a decline for a short or long time at first, then, there was a rise again. Notwithstanding, no change is seen in the unweared materials in No1 and No2 materials. In this case, it can be said that the change of stress in time is also related with pad thickness as well as thermal and mechanic features. This situation is clearly seen in $6 \mathrm{~mm}$ weared Nol and No2 materials.

The amount of stress also rises with the rise of wear amount. This situation demonstrates that the life of pad dies out not linearly but rapidly depending on the rise of wear amount. In the cases where the elasticity module and thermal expansion parameter are low in the materials, in the strain analysis carried out in $300 \mathrm{~s}$ time, it will be seen as a result of the analyses made that the stresses decrease at first properly and they rise later [14].

\section{Conclusions and recommendations}

In this study, the temperature distributions and stress situations of four different pad materials during $300 \mathrm{~s}$ occurring as a result of permanently braking were examined using SolidWorks Simulation Solutions packet program with finite element method. In the study, in order to consider the impact of pad's wear, two pads of different thicknesses were examined as well.

The main results attained at the end of the study can be listed as:

1. Because the thermal power affecting the pad changes depending on the distance from the center of pad, higher temperature values are obtained towards the outer parts of the pad.

2. The highest temperature values occur on the surface where pad touches the disk.

3. While examining the temperature distribution emerging in the pad, not only the highest temperature but also the difference between the highest and lowest temperatures is to be considered.

4. It has been found out that there is an inverse proportion between the thermal conductivity parameter of material and specific temperature and density. The temperature and temperature difference value occurring on the surface of the pad material whose thermal conductivity parameter and specific heat and density are high become the maximum. The temperature and temperature difference value occurring on the surface of the pad material whose thermal conductivity parameter and specific heat and density are high become the minimum.

5. As the rate of wear increases, the temperature value and difference also increases and it is seen that the deformation formed decreases.

6 . The places that have the biggest stresses are the corner parts which sit the holding surface of pad and the middle channel part of the pad. The most important points in terms of thermal stresses are the thermal expansion parameter and elasticity module. For this reason, while comparing the stresses, these characteristics of the materials should be taken into account. On the other hand, the highest temperature and temperature differences are the factors becoming influential in the occurrence of the stresses. If the thermal expansion parameter and elasticity are big, the value of strain becomes big as well.

7. In all of the pads, at first there is an amount of decrease, then these stresses begin to increase. This decreasing period is short or long depending on the thermal characteristics of materials. In this case, it can be said that the change of strain in time is also related with pad thickness besides the thermal and mechanic features.

8. With the rise of wear amount, the amounts of stress also rises. This situation demonstrates that the life of pad dies out not linearly but rapidly depending on the rise of wear amount.

\section{References}

1. Koç, O. 2008. Results of the friction brake pad including heat transfer system and thermal analysis, Master of Science Thesis, Afyon Kocatepe University, Institute of Science, (In Turkey).

2. Domaç, G.S. 2006. Disc brakes of the design and tribological examination, PhD Thesis, Yildiz Technical University, Institute of Science, (In Turkey).

3. Hohmann, C.; Schiffner K.; Oerter, K.; ve Reese, H. 1999. Contact analysis of drumbrakes and disc brakes using ADINA, Computers \& Structures 72: 185-198. http://dx.doi.org/10.1016/S0045-7949(99)00007-3.

4. Tamari, J.; Doi, K.; Tamasho, T. 2000. Prediction of contact pressure of disc brake pad, Technical Notes, Society of Automotive Engineering, Review 21: 133141.

5. Abu, B.; Huajıang, O.; ve Cao, Q. 2003. Interface pressure distributions through structural modifications, SAE Papers 01-3332.

6. Abu, B.; Huajıang, O. 2005. Prediction of disc brake contact pressure distributions by finite element analysis, Journal Technology, 43(A) Dis. 2005: 21-36.

7. Abu, B.; Huajıang, O. 2007. Wear prediction of friction material using the finite element method, Wear, 264(11-12): 1069-1076. http://dx.doi.org/10.1016/j.wear.2007.08.015.

8. Thomas, V.; Kwangjin, L. 2000. An Analytical Method to Predict Thermal Distortion of a Brake Rotor, SAE 2000-01-0445 World Congress Detroit, Michigan, 109: 566-571.

9. Arpat, S.K. 2001. Minimization of the pad wear on both drum and disc brakes by thermal analysis, Master of Science Thesis, Dokuz Eylül University, Institute of Science, (In Turkey).

10. Jacobsson, H. 2003. Aspects of disc brake judder, Proc. Ins. Mech. Eng. Journal of Automobile Engineering, Part D, 217: 419-430. http://dx.doi.org/10.1243/095440703766518069.

11. Mosleh, M.; Blau, P.J; Dumitrescu, D. 2004. Characteristics and Morphology of Wear, Elsevier Science, Wear, 256:1128-1134.

http://dx.doi.org/10.1016/j.wear.2003.07.007. 
12.Jung, H.H.; Heung, SK.; Young ,C.; Byeong, S.K.; Ki, W.K. 2005. The thermal analysis of brake disc with 3-D coupled analysis, Key Engineering Materials 297300: 305-310.

http://dx.doi.org/10.4028/www.scientific.net/KEM.297 -300.305 .

13. Lijie, L.; Huajiang, O.; Abd, R.; Abu, B. 2008. Transient analysis of car disc brake squeal with temperature effects, Liverpool, England, Automotive Engineering Conference, 5-10.

14. Solid works Simulation Solutions. 2013. Software Engineering Version 2013. Istanbul (TR): User's Manual.

15. Ji, H. C.; In, L. 2004. Finite element analysis of transient thermo elastic behaviours in disk brakes, Elsevier Science, Wear 257:1-21-2, 47-58.

16. Josef, V. 2007. Frictionally excited thermo elastic instability in disc brakes transient problem in the full contact regime, International Journal of Mechanical Sciences 8: 129-137.

17. Koç, O.; Mutlu, İ.; Taşgetiren, S. 2009. Analysis of the friction brake lining including heat transfer system and thermal analysis, Electronic Journal of Vehicle Technologies (EJVT) Vol: 1, No: 2, 89 (1). 9-20.

\section{Timur, H. Kuşçu}

\section{AUTOMOBILIO STABDŽIŲ KALADÉLIŲ ŠILUMOS PERDAVIMAS PO STABDYMO IR TEMPERATŪRINIŲ ITTEMPIŲ ANALIZE்}

\section{R e z i u m è}

Dèl trinties tarp stabdžių kaladèlių ir disko, kuri pagrindinai ịtakoja automobilio eksploatacines charakteristikas, vyksta didelis šilumos išsiskyrimas. Dėl to stabdžių kaladèlèse susidaro pernelyg didelè temperatūra. Laikui bėgant kaladèlès greičiau dyla, atsiranda triukšmas, mažèja stabdžių efektyvumas, ilgèja stabdymo kelias. Siekiant išvengti šių negatyvių pasekmių buvo atlikta daug eksperimentų. Temperatūrinei būklei nustatyti buvo naudotas Solid Works Simulation Solutions modulis. Keturios skirtingos kaladèlių medžiagos buvo bandytos be pertraukos stabdant 300 sekundžių. Dilimo bandymams buvo parinktos dviejų skirtingų storių kaladèlès.

M. Timur, H. Kuşçu

\section{HEAT TRANSFER OF BRAKE PADS USED IN THE AUTOS AFTER FRICTION AND EXAMINATION OF THERMAL TENSION ANALYSIS}

\section{S u m m a r y}

As a result of the friction of brake pads which is one of the factors affecting automobile performances with brake disc, heat energy comes into being. This heat energy causes brake pads to expose to excessive temperature. For this reason, the braking acts of the pads decreases in time and some problems (decrease in the performance of brakes, malfunction, quick pad wear and sound) occur.

In order to eliminate these negative effects emerging on the brake pads, a range of tests were made on pads. To analyze the temperature states of the pads, Solid Works Simulation Solutions module was used. In this program, four different pad materials continually underwent braking act during $300 \mathrm{~s}$ process. In terms of revealing the situation of the pads occurring due to wear, two different thicknesses of the same pad were also taken into consideration in the analyses.

Keywords: heat transfer, thermal tension analysis, wears.

Received March 25, 2013

Accepted January 21, 2014 